Social security regulation in the EU : the de-territorialization of welfare?

Martinsen, Dorte Sindbjerg

Published in:

EU law and the welfare state

Publication date:

2005

Document version

Early version, also known as pre-print

Citation for published version (APA):

Martinsen, D. S. (2005). Social security regulation in the EU : the de-territorialization of welfare? In G. D. Búrca (Ed.), EU law and the welfare state: in search of solidarity (pp. 89-111). Oxford University Press. The collected courses of the Academy of European Law Vol. 2 No. 14 


\title{
4
}

\section{Social Security Regulation in the EU: The De-Territorialization of Welfare?}

\author{
DORTE SINDBJERG MARTINSEN
}

Although the European Union (EU) has not formally been assigned welfare policy competence, it has for decades regulated social benefits between the Member States. The social rights and obligations of the European migrant have for long been safeguarded by the EU, and the mutual responsibility for welfare undertaken by the Member States of the Union constitutes an extraordinary piece of 'Social Europe'.

This chapter examines the integration of national social security schemes that has taken place in the European Union through Community Regulation 1408/71, ${ }^{1}$ which has recently been substantially reformed with the adoption of Regulation 883/2004. ${ }^{2}$ The chapter seeks to demonstrate that a dimension of European social security has for long been a material fact, patched up by judicial activism and political compromises. A more general description will be drawn of how intra-European welfare has been extended to all citizens of the Union in parallel with the extension of the free movement principle to persons. The focus of the chapter is, however, on the question of exportable welfare between Member States; it describes how the tension between the Community principle of exportability and national principles of territoriality has over time intensified, been reconciled, and reappeared.

The chapter falls into five main parts. First, the European dimension of welfare as established through social security coordination will be introduced. Second, historical recourse will be taken to describe the europeanization process of migration control and access to national welfare. The third part asks to whom intra-European social security applies. The fourth part analyses in greater detail the extent to which welfare has been de-territorialized in the EU. Finally, the chapter provides some concluding remarks on the evolution of the European dimension of social security, and the relation between law and politics in the course of welfare integration.

1 Regulation (EEC) No. 1408/71 of the Council of 14 June 1971 on the application of social security schemes to employed persons, to self-employed persons, and to members of their families moving within the Community.

2 Regulation (EC) 883/2004 of the European Parliament and of the Council of 29 April 2004 on the coordination of social security systems. OJ L 166, 30.04.2004, p. 0001-0123. 


\section{THE EUROPEAN DIMENSION OF WELFARE}

Regulation 1408/71 was adopted as a social complement to the free movement of workers and has developed in parallel with the gradually extended right of free movement. Both the right to free movement for persons within Europe and the right to transnational welfare are from an empirical as well as a theoretical point of view remarkable examples of integration, where rights are gradually decoupled from a person's status as a worker, and where complexes of rules intervene fundamentally with the national competence to decide on the access to and the reach of welfare.

The general purpose of the Regulation is to promote intra-European migration by ensuring that someone who moves and settles in another Member State will not lose their social security entitlements or jeopardize them. The Regulation prescribes that the European migrant has social security rights equal to the settling state's own nationals, as well as having a right to export acquired welfare entitlements, should one live in a different Member State than the one of social affiliation. The implementation of these Community prescriptions means that the Regulation prohibits national legislation that discriminates against a migrant from another Member State, as well as partly prohibiting the territorialization of national benefits through residence clauses.

The Regulation is based on Article 42 of the Treaty (ex. Art. 51), which obliges the Council to adopt the necessary measures regarding social security to provide freedom of movement for workers. Since 1981, when the Regulation was extended to cover self-employed persons, amendments have also been adopted through the use of Article 308 of the Treaty (ex. Art. 235), this constituting the legal basis in conjunction with Article 42. ${ }^{3}$ The continuous use, since 1981, of Article 308 has been fundamental to the development of Regulation 1408/71 and has allowed for this social instrument to be extended beyond a literal interpretation of its Treaty basis. The flexibility provided by Article 308 has, however, been rather controversial, raising questions about the scope and limits of Community competencies.

Regulation 883/2004, formerly $1408 / 71$, is organized around a set of main principles, of which two are to be emphasized here. ${ }^{4}$ The principle of equal treatment applies without exception and sets aside provisions in national legislation which reserve certain benefits for own nationals or long-term residents. The principle of exportability stipulates that acquired rights are exportable within the geographical scope of the Regulation. Exportability challenges the traditional territorial boundedness of social security as laid down in national law and policy. However, unlike the principle

3 D. Pieters, 'Towards a Radical Simplification of the Social Security Co-ordination', in P. Schoukens (ed.), Prospects of Social Security Co-ordination (1997) at 182-3.

4 Other ruling principles are, inter alia, the principle of aggregation, meaning that social security rights acquired in one state are added to rights earned by working or residing in another state, and the principle of lex loci laboris, meaning that the applicable legislation is, in general, that of the state where the work is carried out. 
of equal treatment, exportability is not an absolute principle. Benefits-in-kind can still be demarcated within the national territory without contradicting Community law. ${ }^{5}$ The case law of the European Court of Justice (ECJ), clarifying the scope of exportability, has, however, been criticized for eroding the principle of territoriality on a general basis-which will be examined in more detail below. ${ }^{6}$ The subsequent analysis suggests that the Community mobilization of social services and benefits has conflicted with the traditional geographical reach of welfare, the latter being nation-state bound.

The recent amendment of the Regulation has updated and extended its material scope, ${ }^{7}$ so that today it covers a very extensive range of material benefits, applying to all national social security legislation on: (a) sickness benefits; (b) maternity and equivalent paternity benefits; (c) invalidity benefits; (d) old-age benefits; (e) survivors' benefits; ( $\mathrm{f}$ ) benefits in respect of accidents at work and occupational diseases; ( $\mathrm{g}$ ) death grants; (h) unemployment benefits; (i) pre-retirement benefits; and (j) family benefits. At the same time, social assistance is explicitly placed outside the Regulation. ${ }^{8}$ Much of the political, legal, and administrative dispute on the material scope of the Regulation has concerned the definition of the boundaries between social security on the one hand and social assistance on the other, and thus the definition of the scope and limits of intra-European welfare.

\section{A. Social Security versus Social Assistance}

The boundary set between social security and social assistance dictates the benefits to which the principles of equal treatment and exportability apply.

When Regulation 1408/71 was adopted, its substantive scope seemed reasonably clear. On the one hand social security benefits were included, exhaustively listed in the Regulation. The prime characteristics of national social security schemes again seemed fairly obvious. The general characteristic of social security was, and still is, that security from social risks is offered by public schemes through which specific categories of persons are, compulsory or voluntarily, insured against defined social risks. The schemes are generally financed by collectively paid contributions. The beneficiary of social security schemes is entitled to benefits according to a legally defined position, which mirror the individual contributions paid. The level of benefits is likewise legally specified and is independent of income. ${ }^{9}$

5 G. Haverkate and S. Huster, Europäisches Sozialrecht (1999) at 123.

6 P. Altmaier, 'Europäisches koordinerende Sozialrecht-Ende des Territorialitätsprinzip?' in E. Eichenhofer and M. Zuleeg (eds.), Die Rechtsprechung des Europäischen Gerichtshofs zum Arbeits- und Sozialrecht im Streit (1995) 71-93 at 71.

7 Before the adoption of Regulation 883/2004, 1408/71 covered: (a) illness and maternity; (b) invalidity benefits; (c) old-age pensions; (d) survivors' benefits; (e) occupation-related accidents and disease; (f) death grants; (g) unemployment benefits; (h) family benefits.

8 As laid down by Art. 3(5) of Regulation 883/2004.

9 A. P. Van der Mei, 'Regulation 1408/71 and Coordination of special Non-Contributory Benefit Schemes', 27 European Law Journal (2002) 551-6. 
On the other hand, it excluded social assistance benefits as laid down in Article 4(4). Social assistance was, and is, different in nature, consisting in what the state offers its citizens or long-term residents who are not able to provide for themselves, and have no alternative financial means. Social assistance is usually granted on a discretionary basis, within which a means test is likely to play a part. In contrast to social security, social assistance schemes are non-contributory, financed by tax revenues. However, previous tax payment is not a criterion for entitlement. ${ }^{10}$ Social assistance policies have traditionally been based on the principle of territoriality.

The distinction between the two types of benefit has become increasingly blurred over the years. As national welfare systems have developed, they have increasingly combined aspects of the two types of benefit. The new mixed nature of some benefits means that, today, social security may be granted on the basis of a means test, while social assistance may increasingly be a legally enforceable right. ${ }^{11}$ The right of the European migrant to be eligible for or to export those benefits which may be defined as, or resemble, social assistance has been one of the most controversial issues in the history of the coordination system and continues to be so to date, as will be demonstrated below.

\section{EUROPEANIZING MIGRATION CONTROL AND ACCESS TO NATIONAL WELFARE}

The Community objective of free movement of workers as well as the coordination of their social security rights were introduced from a strictly economic point of view. Both the right to settle in another Member State and also the right to access the social security rights of the host state were linked to the person's status as a worker. Against this historical background, the recent extension of the right to free movement and cross-border welfare to persons, irrespective of their economic activity, stands out even more starkly as an example of integration.

Long before the existence of the European Coal and Steel Community, the conditions of European labour migration and the social entitlements of migrants were negotiated between European states. ${ }^{12}$ Bilateral agreements between individual countries became the early regulatory modus, where rights and obligations in general favoured the labour-importing country. In this context of 'bilaterally organized interdependence', ${ }^{13}$ the Treaty of Paris became the potential frame in which to

10 A. P. Van der Mei, 'Regulation 1408/71 and Coordination of special Non-Contributory Benefit Schemes', 27 European Law Journal (2002) 551-6.

11 Pieters, supra n. 3 at 207.

12 See J. Holloway, Social Policy Harmonization in the European Community (1981); F. Pennings, Introduction to Social Security Law (1998); E. Eichenhofer, Sozialrecht der Europäischen Union (2001).

13 See F. Romero, 'Migration as an Issue in European Interdependence and Integration: The Case of Italy', in A. Milward et al. (eds.), The Frontier of National Sovereignty: History and Theory 1945-1992 (1993) 35-59, for his discussion of the era of 'bilaterally organised interdependence'. 
negotiate new multilateral provisions. Article 69 of the Paris Treaty became the first, quite reluctant, step taken at Community level to allow for worker mobility. The right, however, was only conferred on workers of 'proven qualifications' and thus from early on reflected the economic purpose of free movement. It was agreed that the limited circulation of workers of 'proven qualifications' should be complemented by a Community provision on their social security situation. ${ }^{14}$ Social protection as attached to labour mobility was initiated by Article 69(4) of the Paris Treaty.

Article 48 of the Treaty of Rome went one step further. The founders of the European Economic Community had agreed to grant free movement for workers, and obliged one another to remove those aspects of national legislation that discriminated on the basis of nationality within a twelve-year transition period. With Regulation 1612/68 and Directive 68/360,15 actual free movement for workers was institutionalized in $1968 .{ }^{16}$ In the early 1970 s, workers and their families were granted the right to remain in a host state ${ }^{17}$ and free movement was equally extended to the self-employed person and his/her family members. Article 51 of the Treaty of Rome supplemented Article 48 and laid down the social security measures to be taken in order to achieve labour mobility. On behalf of the Treaty provision on the coordination of social security, Regulation 1408/71's predecessor, Regulation 3/58, was adopted in the same year that the Treaty of Rome entered into force. Regulation 3/58 became the first major piece of legislation in the European Community. ${ }^{18}$ This substantiates the centrality of social security coordination and affirms that although welfare policies were-and are-formally regarded as national competencies, their impediment to the free movement of labour as a production factor was addressed from the very start and in a very intensive way. When Regulation 1408/71 was adopted, it inherited the provisions of its predecessor, but improved some of the regulatory gaps and unclear definitions, as had been pointed out in the early litigation in the ECJ.

The year 1990 witnessed the next landmark on the path to free movement of persons within the Community. With the Council's adoption of the three residence directives in June $1990,{ }^{19}$ the right to reside culminated in the extension of free movement to all Member State citizens, granting the right of free movement to

14 Haverkate and Huster, supra n. 5 at 88.

15 Council Regulation (EEC) No. 1612/68 of 15 October 1968 on freedom of movement of workers within the Community (OJ L 257, 19.10.1968, p. 2); Council Directive 68/360/EEC of 15 October 1968 on the abolition of restrictions on movement and residence within the Community for workers of Member States and their families.

16 J.-Y. Carlier and M. Verwilghen, 'Foreword', in J.-Y. Carlier and M. Verwilghen (eds.), Thirty Years of Free Movement of Workers in Europe (2000) at 7-9.

17 Regulation (EEC) No. 1251/70 of the Commission of 29 June 1970 on the right of workers to remain in the territory of a Member State after having been employed in that State.

18 Holloway, supra n. 12 at 260.

19 Council Directive 90/364/EEC of 28 June on the right of residence (OJ L 180, 13.7.1990, p. 26); Council Directive 90/365/EEC of 28 June 1990 on the right of residence for employees and self-employed persons who have ceased their occupational activity (OJ L 180, 13.7.1990, p. 28) and 93/96/EEC of 29 October 1993 on the right of residence for students (OJ L 317, of 18.12.1993, p. 59). 
the respective categories of students, retired persons, and economically inactive persons. Although apparently decoupling the right to reside in other Member States from the exercise of economic activity, the extension was made on condition that the three categories of non-workers and their families were covered by health insurance and had sufficient resources to avoid becoming a burden on the social assistance system of the host Member State. In practical terms a residence permit, issued by the host state, ensured that ultimately it was still a national matter to control the immigration of European citizens. Union citizenship, introduced by the Maastricht Treaty in 1992, and the right conferred on every Union citizen to move and reside freely merely codified the right which had already been adopted by the residence directives. Nevertheless, Union citizenship became the future reference point from which to consolidate the rights of the non-active person.

For those who thought that the residence directives and the largely formalistic notion of Union citizenship in the Maastricht Treaty were as far as Europe could go in terms of europeanizing the competence to decide who resides on national territory, the content of the recently adopted residence Directive 2004/38/EC ${ }^{20}$ must be another upset. The Directive eliminates the obligation for EU citizens to obtain a residence permit. It introduces a permanent right of residence after five years of continuous residence. Furthermore, it restricts the scope for national authorities to refuse or terminate the residence of EU citizens. Finally, the new residence rights for all EU citizens, including non-active persons, mean that the social assistance schemes of another Member State become accessible to a greater extent. The Directive stipulates that entitlement to the social assistance of another Member State in the future will depend on the residence status of the EU citizen rather than on more discretionary conditions as set out in the residence directives and national legislation.

Those who have resided for less than five years in a host Member State, will enjoy the right of residence as long as they do not become an unreasonable burden on the social assistance system of the new state of residence and are covered by health insurance in the host Member State. So far the conditions echo those found in the three residence directives. However, the administrative discretion to expel an EU citizen due to his need for social assistance is clearly limited by the new Directive:

... an expulsion measure should not be the automatic consequence of the recourse to the social assistance system. The host Member State should examine whether it is a case of temporary difficulties and take into account the duration of residence, the personal circumstances and the amount of aid granted in order to consider whether the beneficiary has become an unreasonable burden on its social assistance system and to proceed to his expulsion. ${ }^{21}$

20 Directive 2004/38/EC of the European Parliament and of the Council of 29 April 2004 on the right of citizens of the Union and their family members to move and reside freely within the territory of the Member States amending Regulation (EEC) No. 1612/68 and repealing Directives 64/221/EEC, 68/360/EEC, 72/194/EEC, 73/148/EEC, 75/34/EEC, 75/35/EEC, 90/364/EEC, 90/365/EEC, and 93/96/EEC (OJ L 158, 30.4.2004).

21 Directive 2004/58/EC, Para. 16; see also Art. 14.3 of the Directive. 
When it comes to the EU citizen who has been granted permanent residence after five years of residence, he/she will enjoy full social protection in the new Member State and thus also be entitled to social assistance. The Directive stipulates that the right to permanent residence shall not be subjected to conditions of sufficient resources to provide for oneself. That also applies to family members from non-community countries:

Union citizens who have resided legally for a continuous period of five years in the host Member State shall have the right of permanent residence there. This right shall not be subject to the conditions provided for in chapter III. ${ }^{22}$

How the new residence rights and the extended right to access of the welfare protection of another Member State will be transformed into the practical politics of each Member State essentially depends on the national implementation of the Directive which is set to take place within two years from its adoption. The scope of the new material rights subsequently depends on the ECJ's interpretation of such implementation. However, the literal reading of the Directive makes clear that the Member States have approved a much greater social responsibility for each others' citizens.

\section{INTRA-EUROPEAN SOCIAL SECURITY_FOR WHOM?}

The personal scope of Regulation 1408/71 has undergone a gradual, but continual development. From entitling only the worker sensu stricto, i.e., the market citizen, ${ }^{23}$ to cross-border welfare, its personal scope has been incrementally expanded to the point where by 29 April 2004 the Regulation has been extended to all European citizens and where, recently, legally residing third-country nationals have been included in its personal scope. The development is thus a specific reflection of the general development from economic community to political union. The current personal scope of the Regulation has been settled through a detailed legal-political dialogue, consisting of piecemeal judicial interpretations, Commission proposals, and the Council's codification. ${ }^{24}$

22 Ibid. Art. 16.1.

23 The concept of 'market citizen', as it is used here, refers to someone who exercises economic activity and the worker sensu stricto refers to someone with a contract of employment; see J. Shaw, 'European Citizenship: The IGC and Beyond', 1 European Integration online Papers (1997), available online at http://eiop.or.at/eiop/texte/1997-003a.htm; M. Everson, 'The Legacy of the Market Citizen', in J. Shaw and G. More (eds.), New Legal Dynamics of European Union (1995) 73-90.

24 For a more detailed description of the gradual process see, among others, Holloway, supra n. 12; B. Schulte, Europäische Sozialpolitik und die Zukunft des Sozialstaats in Europa: Herausforderungen und Chancen (1998); G. Igl, 'Pflegerversicherung als neuer Gegenstand sozialrechtlicher Regulierung', in K. Sieveking (ed.), Soziale Sicherung bei Pflegebedürftigkeit in der Europäischen Union (1998) 19-37; Haverkate and Huster, supra n. 5; A. Christensen and A. Malmstedt, 'Lex Loci Latoris versus Lex Loci Domicilii: An Inquiry into the Normative Foundations of European Social Security Law', 2 European Journal of Social Security (2000) 69-111; F. Pennings, 'The European Commission Proposal to simplify 
April 2004 perhaps marks the most remarkable extension of Regulation 1408/71's personal scope, and thus temporarily closes the long-running history of defining those with a right to cross-border social security. With the adoption of Regulation $883 / 2004$, the right to coordinated social security has been extended to all nationals of Member States covered by the social security legislation of any Member State. This means that not only employed workers, self-employed workers, civil servants, students, and pensioners but also non-active persons are to be protected from the coordination rules. Furthermore, as of 1 June 2003, nationals from third countries as well as their family members and survivors, provided that they are legal residents in the territory of a Member State and that they have moved between Member States, are covered by the Regulation. ${ }^{25}$ Although, on the face of it the inclusion of third-country nationals marks another, significant, step towards a generalized personal scope irrespective of nationality, the practicable rights of third-country nationals are much more restricted, since they lack the underlying right of free movement.

The inclusion of non-active persons and third-country nationals marks the provisional conclusion of a 'long-running saga'. ${ }^{26}$ Traditionally, the Regulation has entailed a criterion of Community nationality, waived only for refugees, stateless persons, and family members. This meant that a third-country national would not enjoy any rights according to Regulation 1408/71, unless he or she was a family member of a Community national — in which case nationality became irrelevantor else he or she was a refugee or a stateless person. The Regulation thus clearly discriminated against third-country workers despite their possibly considerable contributions to a Member State's economy. Apparently, the amendment adopted in 2003 put an end to an intense debate between the Commission, Council, Parliament, and Court on the status of third-country nationals, and finally granted equal rights to a previously deprived group. However radical such an extension may seem, it should be noted that in practice it is not of much use. Third-country nationals legally residing in Member States have no right to free movement, but they can only invoke the rights under Regulation 1408/71 if they do move between Member States. Furthermore, Denmark is not bound by the recent amendment, due to its exemption from the Treaty's Title IV on 'Visas, Asylum, Immigration and Other Policies related to the Free Movement of Persons'. Third-country nationals

Regulation 1408/71', 3 European Journal of Social Security (2001) 45-60; D. S. Martinsen, Who Has the Right to Intra European Social Security? From Market Citizens to European Citizens and Beyond, EUI Working Paper, Department of Law (2003) 13, 1-48.

25 As laid down by Council Regulation (EC) No. 859/2003 of 14 May 2003 extending the provisions of Regulation (EEC) No. 1408/71 and Regulation (EEC) No. 574/72 to nationals of third countries who are not already covered by those provisions solely on the ground of their nationality.

26 S. Peers, 'Joined Cases C-95/99 to 98/99, Mervett Khalil and others v. Bundesanstalt für Arbeit and Landeshauptsadt Stuttgart and Case C-180/99, Meriem Addou v. Land Nordrhein-Westfalen, judgment of the Full Court of 11 October 2001 [2001] ECR I-7413', 39 Common Market Law Review (2002) $1395-406$ at 1395 . 
who enter Danish territory from another Member State or leave the Danish territory bound for another Member State thus continue to have variable protection levels.

Another long-running dispute has been whether the Regulation should include non-active persons and thus definitively break the link with the exercise of an economic activity. Over the years, the case law of the ECJ has compromised the link between work activity and rights according to the Regulation, by extending rights to those no longer in active employment, but still enjoying the status of 'employed persons' ${ }^{27}$ by clarifying that movement motivated by leisure may generate rights; ${ }^{28}$ by extending the rights of family members; ${ }^{29}$ and by denying that employment status depends on the hours spent on the work activity. ${ }^{30}$ Through successive case law, the Court has declared that the migrant's family has an individual right to equal treatment, ${ }^{31}$ that the meanings of employed ${ }^{32}$ and selfemployed $^{33}$ are extensive, and that the number of hours spent working does not influence one's status as a worker in any way. The legal reasoning has thus approached a practical recognition of European citizenship.

The Court's interpretative line has been seconded by the Commission. Since the adoption of the general right of residence in 1990 with the three residence directives, the Commission has persistently used the soft-law tool of recommendations to emphasize how 'the peoples of Europe' merit equal rights, and has brought in European citizenship as the new dimension of European integration.

The Council and the Parliament have recently adopted Regulation 883/2004, on the agenda since the early 1990s, which definitively extends the right to intraEuropean social security to all 'nationals of a Member State, stateless persons and refugees residing in a Member State who are or have been subject to the legislation of one or more Member States, as well as to the members of their families and to their survivors'. ${ }^{34}$ The extension of intra-European social security rights to all Community nationals adds substantial rights to the skeleton of European citizenship, since cross-border social rights are, finally, granted irrespective of economic activity. However, as long as the right to move and reside within the Community is, for the first five years of foreign settlement, conditioned by the ability to provide for oneself, the 'social self' of Europe will still ultimately be subordinated to

27 Case 75/63, Mrs. Hoekstra (née Unger) v. Bestuur der Cont. Bedrijfsvereniging voor Detailhandel en Ambachten, 19 March 1964, ECR 1964, p. 177.

28 Case 44/65, Hessische Knappschaft v. Maison Singer et Fils, 9 December 1965, ECR 1965, p. 1191.

29 Case 7/75, Mr. and Mrs. Fracas v. Belgian State, 17 June 1975, ECR 1975, p. 679.

30 Case C-2/89, Bestuur van de Sociale Verzekeringsbank v. G. J. Kits van Heijningen, 3 May 1990, ECR 1990, p. 1755.

31 Case C-308/93, Bestuur van de Sociale Verzekeringsbank v. J. M. Cabanis-Issarte, 30 April 1996, ECR 1996, p. I-2097.

32 Case 17/76, M. L. E. Brack, widow of R. J. Brack v. Insurance Officer, 29 September 1976, ECR 1976 , p. 1429.

33 Case 300/84, A. J. M. van Roosmalen v. Bestuur van de Bedrijfsvereniging voor de Gezondheid, Geestelijke en Maatschappelijke Belangen, 23 October 1986, ECR 1986, p. 3097.

34 Regulation 883/2004, Art. 2. 
economic imperatives. ${ }^{35}$ In reality, 'work' or 'economic status' will continue to be the entry point into another Member State for the majority of European migrants, and still constitute the basic condition upon which foreign social rights are granted.

For the time being, the Community Regulation on coordinated social security, through its confirmed link with the provision on the free movement of workers, ${ }^{36}$ is essentially legitimated by market integration. However, since the path to social security integration has proven to be incremental, albeit dynamic, and with a high degree of issue linkage between different economic, legal, and political rationales, the substance and reach of future cross-border social security rights are difficult to predict. There can be no doubt that, with the historical development and contemporary achievements, we have witnessed the formation of a key part of Europe's social identity.

\section{THE DE-TERRITORIALIZATION OF WELFARE?}

The formation and consolidation of modern social policies took place within the territorial borders of the nation-state. Welfare policy was, and remains, closely related to the idea of the nation-state. ${ }^{37}$ The welfare state inherited the nation-state method of defining those entitled and its strong emphasis on territoriality. The welfare state has traditionally been in a sovereign position to exercise spatial control, insisting that social benefits and services should be consumed within its own territory. ${ }^{38}$ Alongside social citizenship, ${ }^{39}$ the principle of territoriality has demarcated the reach of European welfare.

35 For a description of Europe's social self, see M. P. Maduro, 'Europe's Social Self: The Sickness unto Death', in J. Shaw (ed.), Social Law and Policy in an Evolving European Union (2000) 325-49.

36 That Regulation 1408/71 has not yet achieved status as an independent instrument of social protection was confirmed by the dispute between the Commission and the Member States on the extension of the Regulation to third-country nationals and whether this extension could be based on Art. 42 of the Treaty, as held by the Commission, or should be based on the Treaty's Art. 63(4), as argued by individual Member States. According to a minority of the Member States, an extension of the Regulation to third-country nationals could not be based on Art. 42 since they saw this provision inextricably bound to Art. 39 of the Treaty, the objective of which is to promote the free movement of workers, who are nationals of one of the Member States. The Commission, on the other hand, argued that Regulation $1408 / 71$ had become an instrument of social protection in itself and not only a means to achieve the free movement of workers. For a more detailed description of the dispute, see D. S. Martinsen, European Institutionalization of Social Security Rights: A Two-Layered Process of Integration (2004), Ph.D. thesis, European University Institute, and supra n. 24.

37 Eichenhofer, supra n. 12 at 55.

38 S. Liebfried and P. Pierson, 'Semisovereign Welfare States: Social Policy in a Multitiered Europe', in S. Liebfried and P. Pierson (eds.), European Social Policy: Between Fragmentation and Integration (1995) 43-77.

39 Social citizens were traditionally those who were members of the nation. Concepts such as equality and solidarity were not unlimited, but restricted to members of the nation. T. H. Marshall's depiction of 'social citizenship' stands to date as perhaps the most often referred to. He wrote: 'Citizenship is a status bestowed on those who are full members of a community. All who possess the status are equal with respect to the rights and duties with which the status is endowed' (T. H. Marshall, 
Social legislation in the EU Member States largely remains based on the principle of territoriality, defining the spatial application of welfare. ${ }^{40}$ Even in a globalized world, the principle still finds its justification in practical politics. Social benefits and services are designed to fulfil domestic policy aims and correspond to domestic living conditions and costs. ${ }^{41}$ Above all, the principle serves as an effective means of national control:

- It ensures budgetary control, by entitling only those residing and consuming within the national borders to the benefits and services supplied.

- It ensures that the intended policy and its objective are actually pursued. To ensure, for example that long-term care benefits are used for actual care and that supplied family benefits meet policy intentions.

- It serves as a means of controlling the quality of supplied services, since standards are nationally defined.

- It facilitates capacity planning, since when services can only be consumed within national borders, consumption is nationally controlled and foreign supply does not have to be integrated.

Whereas, by the adoption of Regulation 1408/71, Member States applied the principle of exportability to social security benefits at least for those supplied in cash, an intense dispute has taken place between the ECJ, individual states, and the Council as to: (a) whether those benefits, characterized as special non-contributory benefits, due to their affinities with both social security and social assistance, are exportable; (b) whether Community law extends welfare policy objectives, such as those embedded in certain family benefits, beyond national borders; and (c) whether Community law prescribes the exportability of more recently accepted social responsibilities such as those undertaken by long-term care benefits. On the one hand, the dispute, exercised through legal requests, ECJ case law, and Council responses, mirrors the intervention of an internal market principle into the national organization of welfare. On the other hand, the dispute also mirrors how politics and national preferences may overrule judicial activism undertaken by the ECJ. However, more contemporary developments suggest that such restraints are not ultimate. Recent ECJ decisions have questioned anew the territorialization of certain welfare benefits. The sections below will examine in turn the exportability of special non-contributory benefits, family benefits, and long-term care.

Citizenship and Social Class and Other Essays (1992) at 18). The European integration of social security rights has indeed transformed, or even eroded, this traditional notion of social citizenship, as is clear from the extension of Regulation 1408/71's personal scope depicted above.

40 Haverkate and Huster, supra n. 5 at 115.

41 W. Tegtmeier, 'Wechselwirkungen zwischen dem Europäischen Sozialrecht und dem Sozialrecht der Bundesrepublik Deutschland: Erfahrungen und Vorstellungen auf deutscher Sicht', in B. Schulte and H. F. Zacher (eds.), Wechselwirkungen zwischen dem Europäischen Sozialrecht und dem Sozialrecht der Bundesrepublik Deutschland (1990) 27-47; P. Clever, 'Soziale Sicherheit im Rahmen der europäischen Integration: Perspektiven nach dem Maastrichter Gipfel', 39 Die Angestelltenversicherung (1992) 296-304. 


\section{A. Special Non-Contributory Benefits within National Borders}

One of the first cases examining the spatial reach of 'special non-contributory benefits' was that of Piscitello, concerning the Italian social aid pension. ${ }^{42}$ Despite the opinions submitted by Member States, which argued that the social aid pension had strong affinities with social assistance, the Court ruled that the benefit was exportable according to Community law.

The legal-political confrontation over the nature of 'special non-contributory' benefits culminated with the assessment of the French supplementary allowance, expressed in Joined Cases 379 to 381/85 and 93/86 Giletti et al.43

The French government argued in its observations that the nature of the benefit was that of assistance. The supplementary allowance could not be classified as social security, because (1) it was not financed by contributions, but by public funds, (2) it was not related to occupation, but was a matter of national solidarity, and (3) the objective of the national allowance was to alleviate a state of need and, therefore, took the personal income of the receiver into consideration.

The ECJ, however, disregarded the national observations. The Court stated that, although the benefit was financed out of tax revenue and aimed to provide a minimum level of income for the recipient, it was an old-age benefit within the meaning of Regulation 1408/71, since it was granted as a legally protected right. The Court furthermore overruled the French residence clause, holding that in accordance with Community law the supplementary allowance was exportable.

However, despite the Court's conclusions, France still refused to comply, and the dispute on the supplementary allowance went on. Against this background, the Commission issued an infringement procedure, Case C-236/88 against France, against the French residence clause for the supplementary allowance. The Court again concluded that the French authorities were obliged to allow for the exportability of its old-age benefit.

The legally imposed exportability of the French supplementary allowance did not, however, last long. On the 30 April 1992, the Council of Ministers unanimously adopted Regulation 1247/92,44 which overruled the Court's extension of exportability. The collective political response stood out clearly. The interpretations of the Court exceeded political intentions. The Council managed to overcome the significant

42 Case 139/82, Paola Piscitello v. Instituto Nazionale della Previdenza Sociale (INPS), 5 May 1983, ECR 1983, p. 1427.

43 Joined Cases 379 to 381/85 and 93/86, Caisse régionale d'assurance maladie Rhone-Alpes v. Anna Giletti, Directeur régional des affaires sanitaires et sociales de Lorraine v. Domenico Giardini, Caisse régionale d'assurance maladie du Nord-Est v. Federico Tampan and Severino Severini v. Caisse primaire centrale d'assurance maladie, 24 February 1987, ECR 1987, p. 955. See also Eichenhofer, supra n. 12 at 80; Christensen and Malmstedt, supra n. 24 at 82.

44 Council Regulation (EEC) No. $1247 / 92$ of 30 April 1992 amending Regulation (EEC) No. $1408 / 71$ on the application of social security schemes to employed persons, to self-employed persons, and to members of their families moving within the Community. 
threshold of unanimous political action, and the unintended case law development was halted.

Regulation 1247/92 amended 1408/71, and added a 'special rule' to the coordination system. The 'special rule' meant that special non-contributory benefits were included in the material scope of Regulation 1408/71, and rights awarded between Member States could thus be aggregated, but that the benefits remained bound to the territory of the competent state and could not be exported. For a benefit to be coordinated according to the 'special rule', it should be listed in Annex IIa of the Regulation. Among other benefit types, Annex IIa came to list the French supplementary allowance from the National Solidarity Fund; 45 the Italian social pensions for persons without means; ${ }^{46}$ the British attendance allowance, ${ }^{47}$ disability living allowance, ${ }^{48}$ and family credit. The Member States thus retained control over the spatial reach of these benefits.

The amendment corrected the expansionary course taken by the Court, and adopted a system within the system allowing for 'special non-contributory benefits' to be territorialized anew. In the subsequent case of C-20/96 Snares, ${ }^{49}$ the Court was requested to interpret the compatibility of the special rule with Article 51 of primary law. The case questioned whether the territorial binding of the British disability living allowance was not contrary to the essence and purpose of Article 51, namely to promote the free movement of migrant workers. The ECJ, however, chose to accept the political derogation over its previous judgments, codified by Regulation 1247/92, and decided that British legislation did not violate Community law, since 'the principle of the exportability of social security benefits applies so long as derogating provisions have not been adopted by the Community legislature' ${ }^{50}$ Case C-297/97 Partridge ${ }^{51}$ followed up on the Snares case, questioning the nature of another British disability allowance, the attendance allowance, which is a benefit awarded to care-dependent persons. The preliminary reference concerned whether the answer given by the Court in the case of Snares also applied to a benefit type such as the attendance allowance. Concretely the case treated the situation of Mrs. Partridge, whose attendance allowance had been withdrawn when she went to live with her son in France. The judgment of the Court reaffirmed the standpoint taken in Snares. The attendance allowance was a special non-contributory benefit, exclusively governed by the rules laid down in Article 10a, and was therefore not exportable outside the territory of the UK.

With the adoption of Regulation 1247/92 and the legal approval thereof in the cases of Snares and Partridge, 'special non-contributory' benefits seemed to have

45 Law of 30 June 1956.

46 Law no. 153 of 30 April 1969.

47 Both as formulated in the Social Security Act 1975, sects. 37A and 35.

48 Disability Living Allowance and Disability Working Allowance Act 1991.

49 Case C-20/96, Kelvin Albert Snares v. Adjudication Officer, 4 November 1997, ECR 1997, p. I-6057.

50 Ibid. Para. 41 of the Judgment.

51 Case C-297/96, Vera A. Partridge v. Adjudication Officer, 11 June 1998, ECR 1998, p. I-3467. 
been definitively re-territorialized. Together the Commission, Court, and Council institutionalized the position that the regulatory text can permit new deviations from the general-but not absolute-principle of exportability. Nevertheless, more recent case law has redrawn our attention to 'the special rule'-and especially to the political administration thereof-as will be demonstrated below with the cases of Jauch and Leclere. On this later date, the ECJ has not acted deferentially to individual political interests.

\section{B. Policy Objectives beyond National Borders: Family Benefits}

Whereas national decision-makers formally decide on the objectives, means, and content of their welfare policies, the lesson taught by the ECJ is that their decisions have to take the scope and limits of European law into account. That welfare policy autonomy has been compromised as a consequence of the dynamic interpretation of Community law is well exemplified by the case of family benefits.

Due to their non-contributory character, different policy objectives, and territorial demarcation, family benefits have been the subject of frequent policy conflict for the coordination system. For the politicians it has not been evident why policies with national demographic aims should equally aim beyond national borders. ${ }^{52}$

Case C-78/91 Hughes ${ }^{53}$ concerned British family credit, and the extent to which it should be categorized as social assistance or rather as a social security benefit. The case considered whether Mrs. Hughes had a right to the British family credit, despite her residence in Ireland, but due to her husband's work in Britain. Since the entitlement to family credit depended on residence in the UK, Mrs. Hughes did not qualify for the benefit. Before the ECJ, both the British and the German government defended the residence clause, arguing that family credit was a social assistance type of benefit. ${ }^{54}$ That national classification was, however, overruled by the judgment. The Court pointed to how it had consistently held that a benefit was a social security benefit if it was granted without discretionary assessment of personal needs, but on the basis of a legally defined position. 55 The conclusion was that the

52 See, among others, Case 41/84, Pietro Pinna v. Caisse d'allocations familiales de la Savoie, 15 January 1986, ECR, p. 1 and Case C-185/96, Commission of the European Communities v. Hellenic Republic, 29 October 1996, ECR 1998, p. 6601. See also S. Van Raepenbusch, 'Persons covered by Regulation (EEC) no. 1408/71 and European Citizenship: From Migrant Worker to European Citizen', in 25 Years of Regulation (EEC) no. 1408/71 on Social Security for Migrant Workers: Post Experiences, Present Problems and Future Perspectives (1997) 71-88.

53 Case C-78/91, Rose Hughes v. Chief Adjudication Officer, Belfast, 16 July 1992, ECR 1992, p. I-4839.

54 The British government clarified that the main purpose of the family credit, a weekly noncontributory cash benefit, was to supplement the incomes of low-paid workers whose income would otherwise be lower than if they were unemployed. The aim of the benefit was to keep low-paid workers in employment, for which reason the government did not find that it was a social security benefit.

55 Case C-78/91, Hughes, supra n. 53, Para. 15 of the judgment. 
principle of exportability in Community law entitled Mrs. Hughes to the family credit, and the Court set aside the residence requirement of British law.

During the 1980s, several Member States introduced different types of 'child-raising' allowances as a new family benefit. A general aim of the benefit was to make it possible for one parent to stay at home with the child during its first years. However, neither national nor community law specified the relationship between the new social benefit and Regulation 1408/71.56 Joined cases C-245/94 and C-312/94 Hoever and Zachow ${ }^{57}$ concerned the German child-raising allowance, i.e. Erziehungsgeld, adopted in December 1985. This type of childcare benefit differed from the traditional German family benefit, i.e. Kindergeld, in its objective and qualifying conditions. ${ }^{58}$ From a German legal, political and administrative perspective, Kindergeld had traditionally been regarded as the only German family benefit within the meaning of Regulation 1408/71.59 The child-raising allowance had, on the other hand, been regarded as outside the regulatory scope of Regulation 1408/71. That point of view was challenged and corrected by the case law of the Court.

The cases of Hoever and Zachow concerned two migrant families, residing in the Netherlands, but with the husbands working full-time in Germany. The wives applied for the German child-raising allowance, without personally being affiliated to the German social security system. Based on the principle of territoriality, the German law on childcare benefit denied Mrs. Hoever and Mrs. Zachow any right to child-raising allowance. Among other criteria, the national law specifies that to qualify for the childcare benefit one must reside in Germany, ${ }^{60}$ or, if not residing there, have worked at least fifteen hours a week in Germany.

In its reasoning, the ECJ referred in particular to the case of Hughes, and restated that it was the constituent elements of each benefit that decided its classification. ${ }^{61}$ Since the German Erziehungsgeld was granted automatically to persons fulfilling objective criteria without any individual or discretionary assessment of needs, it was a family benefit within the meaning of Article 4(1)(h). ${ }^{62}$

56 Altmaier, supra n. 6 at 86.

57 Joined Cases C-245/94 and C-312/94, Ingrid Hoever and Iris Zachow v. Land NordrheinWestfalen, 10 October 1996, ECR 1996, p. I-4895. The Erziehungsgeld is governed by the German Bundesgesetz über die Gewährung von Erziehungsgeld und Erziehungsurlaub.

58 G. Igl, 'Co-ordination and New Forms of Social Protection', in 25 Years of Regulation (EEC) No. 1408/71 on Social Security for Migrant Workers: Past Experiences, Present Problems and Future Perspectives (1997) 91-111 at 97.

59 E. Eichenhofer, 'Deutsches Erziehungsgeld und Europäisches Sozialrecht: zur Entscheidung des Europäischen Gerichtshofes vom 10.10.1996-verbundene Rechtsache C-245/94 und C-312/94 Ingrid Hoever und Iris Zachow/Land Nordrhein-Westfalen', in 10 Die Sozialgerichtsbarkeit (1997) 449-55.

60 Bundesgesetz über die Gewährung von Erziehungsgeld und Erziehungsurlaub, Para. 1(1).

61 Joined Cases C-245/94 and C-312/94, Hoever and Zachow supra n. 57, Paras. 17 and 18 of the Judgment.

62 Ibid. Para. 27 of the Judgment. 
The second question concerned whether a family member who did not reside in the country where her husband was employed and where the competent institution was situated, and also who was not personally subject to German social insurance, was entitled to the benefit. According to national law, the plaintiff must be personally eligible for the allowance, i.e. must personally fulfil the conditions. In the observations given by the German, Spanish, and French governments, they all referred to the Kermaschek line of case law, ${ }^{63}$ and against this background emphasized that the family member only had a derived right. ${ }^{64}$ However, the Court opposed the stated opinions by restating its conclusions from case Cabanis-Issarte. ${ }^{65}$ The scope of the rule laid down in Kermaschek was limited by Cabanis-Issarte to provisions that were only applicable to workers, and not to family members, such as unemployment benefit. ${ }^{66}$ The Court concluded that the distinction between a personal and a derived right thus did not apply to family benefits, and Mrs. Hoever and Mrs. Zachow were therefore entitled to the childcare allowance. ${ }^{67}$

The joined Hoever and Zachow cases demonstrate a Court that is both willing and in a position to contradict national opinions and the formulated criteria of national law. In the cases, the Court overruled both the territorial principle of German law, and the criterion that one has to be personally eligible for the childcare allowance. It demonstrates a Court that is willing to rule against national preferences, despite the financial implications. By extending Erziehungsgeld beyond German borders, the ability to ensure budgetary control for the specific item of expenditure has been reduced. The litigation furthermore exemplifies how past and future case law relate, establishing different authoritative lines of reasoning, which can be pieced together to formulate new concrete rights for the migrant. The case

63 Case 40/76, Kermaschek v. Bundesanstalt für Arbeit, 23 November 1976, ECR 1976, p. 1669. In the case of Kermaschek, the Court established a restrictive view on the rights of the family member and drew a sharp distinction between, on the one hand, the rights of the worker and, on the other hand, the rights of their families. The family member only had 'derived rights', meaning those acquired by national law through his/her status as a family member. The family member could therefore not rely personally on the principle of equal treatment. The Court maintained the distinction for more than twenty years, confirming it in a line of judgments known as the Kermaschek case law. This line of cases included, among others, the Case 157/84, Maria Frascogna v. Caisse des depots et consignations, 6 June 1985, ECR 1985, p. 1739; Case 94/84, Office national de l'emploi v. Joszef Deak, 20 June 1985, ECR 1985, p. 1873; Case C-243/91, Belgian State v. Noushin Taghavi, 8 July 1992, ECR 1992, p. I-4401; Case C-310/91, Hugo Schmid v. Belgian State, represented by the Minister van Sociale Voorz, 27 May 1993, ECR 1993, p. I-3011.

64 Joined Cases C-245/94 and C-312/94, Hoever and Zachow, supra n. 57, Para. 31 of the Judgment.

65 Case C-308/93, Cabanis-Issarte, supra n. 31. In the Cabanis-Issarte judgement, the Court reconsidered the scope of Regulation 1408/71's equal treatment provision and its application to the family member, and revised the interpretive path of established case law, which had been confirmed through more than twenty years of legal interpretation in the Kermaschek line of case law (Martinsen, supra n. 36 at $120-5)$.

66 Joined Cases C-245/94 and C-312/94, Hoever and Zachow, supra n. 57, Para. 32 of the Judgment.

67 Ibid. Para. 33. 
of Hughes was a reference point for the Court when incorporating Erziehungsgeld into the material scope of Regulation 1408/71. Another reference was CabanisIssarte, which extended the principle of equal treatment to family members. Furthermore, the Hoever and Zachow cases were referred to by the Court in the much-discussed case of Martinez Sala, when concluding that the non-active Martínez Sala also had a right to Erziehungsgeld, despite the fact that she had no residence permit to stay in Germany. ${ }^{68}$ Both the Hughes and the Hoever and Zachow cases were replicated in the recent case C-333/00 Maaheimo, in which the Court considered whether Finnish 'home childcare allowance' should be paid out abroad. ${ }^{69}$ Previous case law formed the basis of the line of reasoning upon which the Court found that the Finnish residence requirement in its home childcare policy was inconsistent with Community law. Once again, the Court set aside the national principle of territoriality.

This cluster of case law has made it increasingly difficult for Member States to disregard Community law, as interpreted by the Court, when trying to tie policy objectives to national territory. On the basis of a patchwork of litigation, principles and aims are applied uniformly to different cases concerning different social security schemes and welfare traditions. The outcomes are, however, similar. The autonomy to define welfare policy means and objectives is compromised by Community law.

\section{Exportability of 'New' Social Responsibilities: Long-Term Care Benefits}

Long-term care benefit represents a benefit that could not easily have been appreciated back when the material scope of Regulation 1408/71 was first laid down. As a matter of fact, long-term care has taken some time to find its name. Although 'reliance on care' has always existed as a social phenomenon, long-term care did not figure as an independent or conceptualized social security risk in European or international conventions at the end of the $1970 \mathrm{s.}{ }^{70}$ Although by no means a 'new'

68 Case C-85/96, Maria Martínez Sala v. Freistaat Bayern, 12 May 1998, ECR 1998, p. I-2691. For an in depth discussion of the Sala case, see, among others: G. More, 'The Principle of Equal Treatment: From Market Unifier to Fundamental Right', in P. Craig and G. De Búrca (eds.), The Evolution of EU Law (1999) 517-55; S. O'Leary, 'European Communities and EEA: Putting Flesh on the Bones of European Union Citizenship', 24 European Law Review (1999) 68-79; R. Langer, 'Der Beitrag des Europäischen Gerichtshofüber gemeinschaftsrechtlichen Gestaltungsvorgaben für das Sozialrecht', in I. Ebsen (ed.), Europarechtliche Gestaltungsvorgaben für das deutsche Sozialrecht: Freizügigkeit, wirtschaftliche Grundfreiheiten und Europöisches Wettbewerbsrecht als Grenzen sozialstaatlicher Suveränität (1999) 43-56; C. Tomuschat, 'Case C-85/96, Maria Martínez Sala v. Freistaat Bayern, Judgment of 12 May 1998, Full Court [1998] ECR I-2691', in 37 Common Market Law Review (2000) 449-57.

69 Case C-333/00, Eila Päivikki Maaheimo, 7 November 2002, ECR 2002, p. I-10087, Paras. 22, 32 , and 33 of the Judgment.

70 Igl, supra n. 58; opinion of Advocate General Cosmas in Case C-160/96, Manfred Molenaar and Barbara Fath-Molenaar v. Allgemeine Ortskrankenkasse Baden-Württemberg, 5 March 1998, ECR 1998, p. I-880. 
social risk, it is a risk which, in some Member States, has only lately become a part of public welfare, and has been institutionalized beyond the more immediate care provided by the family.

Germany adopted its Pflegeversicherungsgesetz as late as 1995, thereby recognizing long-term care as an independent social risk. Before the adoption of the care insurance law, long-term care was publicly granted as a social assistance benefit, or privately provided and financed. ${ }^{71}$ Today any person insured against sickness in Germany is also compulsorily insured in the long-term care scheme. The social insurance is funded from contributions from both worker and employer, and entitles a member ${ }^{72}$ reliant on care to care in a nursing home or in one's own home. If one should desire home care, it is possible to choose care either as a benefit in kind, or as a monthly allowance, i.e. Pflegegeld, where one purchases the care oneself.

The monthly cash allowance has turned out to be the preferred form of home care. From the outset, $80 \%$ of those in home care chose the cash benefit. ${ }^{73}$ However, according to national legislation, the entitlement to the German Pflegegeld is suspended if one takes up residence abroad. ${ }^{74}$ The Pflegegeld thus relies on the territorial principle.

Whether the territorial restriction of the German Pflegegeld contradicts Community law was examined in case C-160/96 Molenaar. 75 The case discussed the right to Pflegegeld of Mr. and Mrs. Molenaar, a Dutch-German couple, working in Germany but living in France. They were both voluntarily insured against sickness in Germany and were, from January 1995, required to pay care insurance contributions, which they did. However, on application, they were informed by the competent German social security fund that they were not entitled to care insurance benefits due to their French residence.

The ECJ initiated its legal reasoning by referring to previous case law, stating that a benefit was to be regarded as a social security benefit if granted 'on the basis of a legally defined position and provided that it concerns one of the risks expressly listed in Article 4(1)' of Regulation 1408/71. ${ }^{76}$ It added that the list in Article 4(1)

71 G. Igl and F. Stadelmann, 'Die Pflegeversicherung in Deutschland', in K. Sieveking (ed.), Soziale Sicherung bei Pflegebedürftigkeit in der Europäischen Union (1998) 37-51 at 37.

72 The member has to complete an insurance period, which from the outset was one year, but then increased in stages to five years in 2000 .

$73 \mathrm{Igl}$, supra n. 24 at 23.

74 The residence clause is laid down by $\$ 34(1)(1)$ of the German Sozialgesetzbuch (Social Security Code) XI.

75 Molenaar, supra n. 70.

76 The Court referred on this point to Case 249/83, Vera Hoeckx v. Openbaar Centrum voor Maatschappelijk Welzijn, Kalmthont, 27 March 1985, ECR 1985, p. 973, Paras. 12-14; Case 122/84, Kenneth Scrivner and Carol Cole v. Centre public d'aide sociale de Chastre, 27 March 1985, ECR 1985, p. 1027, Paras. 19-21; Case C-356/89 Roger Stanton Newton v. Chief Adjudication Officer, 20 June 1991, p. I-3017, Case C-78/91, Hughes, supra n. 53, Para. 15. 
was exhaustive, meaning that a branch of social security not mentioned there was not part of the regulatory scope. ${ }^{77}$ Long-term care, such as the German Pflegeversicherung, was to be regarded as a sickness benefit within the meaning of Article 4(1)(a) of Regulation 1408/71. Having thus included the care allowance within the material scope of 1408/71, the Court continued by examining whether the residence clause of German law could be justified against the Community principle of exportability.

Article 19(1)(a) and (b) ${ }^{78}$ of the Regulation obliged the competent institution to export sickness benefits in cash, but not equally sickness benefits in kind. ${ }^{79}$ However, the monthly cash allowance, Pflegegeld, was defined as a benefit in kind in German law. More specifically, the drafter of the Pflegeversicherungsgesetz defended the point of view that the care allowance constituted a 'benefit in kind-substitute', a Sachleistungssurrogat. ${ }^{80}$ The ECJ did not accept the national classification, but ruled that the German care allowance was indeed a benefit in cash. ${ }^{81}$ As a consequence, the Court concluded that the residence clause in German law conflicted with the principle of exportability of Regulation $1408 / 71.82$

The Molenaar case is another among the later jurisprudence in which the Court corrected the way in which national politics had classified a benefit. The obvious attempt by the German government to restrict long-term care benefit to its own territory, by classifying it as a 'benefit-in-kind substitute' failed. The Molenaar case illustrates the Court's position in the social security field in the late 1990s. It demonstrates a Court capable of expanding the material and exportable rights of the migrant, despite national preferences and despite the financial implications that it may have for the litigating Member State. The legal activism in which the Court engaged in the Molenaar case updated the material scope of Regulation 1408/71, and extended its provision of exportability.

77 On this point, the ECJ referred here to Case C-25/95, Siegfried Otte v. Bundesrepublik Deutschland, 11 June 1996, ECR 1996, p. I-3745.

78 Art. 19(1) of Regulation 1408/71 stated: 'Residence in a Member State other than the competent State-General rules [...]:

(a) benefits in kind provided on behalf of the competent institution by the institution of the place of residence in accordance with the provisions of the legislation administered by that institution as though he was insured with it

(b) cash benefits provided by the competent institution in accordance with the legislation which it administers [...].' (emphasis added)

79 S. Huster, 'Grundfragen der Exportpflicht im europäischen Sozialrecht', in Neue Zeitschrift für Sozialrecht (1999) 10-17.

80 BT-Drucks (Bundestag Drucks) 12/5262, p. 82; M. Zuleeg, 'Die Einwirkung des Europäischen Gemeinschaftsrechts auf die deutsche Pflegeversicherung', in H. Sieveking (ed.), Soziale Sicherung bei Pflegebedürftigkeit in der Europäischen Union (1998) 159-79 at 172.

81 Case C-160/96, Molenaar, supra n. 70, Para. 36 of the Judgment.

82 As laid down by Art. 19(1)(b) of Regulation 1408/71. 


\section{Territorialization Re-Questioned}

The legal-political dispute on the territorialization of those benefits with dual characteristics of social security and social assistance, with policy objectives tied to the national territory and those that resemble benefits-in-kind, has had two different results. On the one hand, the adoption of Regulation 1247/92, and its subsequent legal approval, seemed to have definitively re-territorialized 'special noncontributory' benefits. On the other hand, the Court's expansive interpretations have made different types of family benefits exportable, for family members as well, and have lifted the residence clause for long-term care benefits granted as benefits in cash.

Recent developments demonstrate further that the limits and the scope of Community law are indeed dynamically interpreted. The recent cases of Jauch ${ }^{83}$ and Leclere $^{84}$ show that a legal-political reconciliation such as the one on special noncontributory benefits may only last until a new request is formulated against a Community law background which has meanwhile evolved.

In the cases of Jauch and Leclere, the Court was requested to clarify the scope of Annex IIa. The case of Jauch concerned a German national, residing in Germany, but who had worked in Austria where he was affiliated to the social security scheme. The competent Austrian institution had denied him long-term care, since he was not a habitual resident in Austria, and since the care allowance was listed in Annex IIa of 1408/71 and thus non-exportable. The Austrian government argued before the Court that because the benefit had been admitted in Annex IIa, the residence clause of Austrian law did not contravene Community law. The government supported its view by referring to the previous cases of Snares and Partridge. The Court's judgment, however, followed another established reasoning, laid down in the case of Molenaar:

... while care allowance may possibly have a different legal regime at the national level, it nevertheless remains of the same kind as the German care insurance benefits at issue in Molenaar, and is likewise granted objectively on the basis of a legally defined situation..$^{85}$

The Court thus ruled that the character of the Austrian care allowance was no different from the German Pflegegeld. The Austrian care allowance was therefore to be classified as another sickness benefit in cash, for which reason it was exportable and had invalidly been listed in Annex IIa. In the case of Jauch, the Court set aside not only the Austrian government's definition of its benefit, but it also overruled the praxis of the Council, which had unanimously agreed to list the care allowance in Annex IIa.

83 Case C-215/99, Frederich Jauch v. Pensionsversicherungsanstalt der Arbeiter, 8 March 2001, ECR 2001, p. I-1901.

84 Case C-43/99, Ghislain Leclere and Alina Deaconescu v. Caisse nationale des prestations familiales, 31 May 2001, ECR 2001, p. I-4265.

85 Case C-160/96, Molenaar, supra n. 70, Para. 26 of the Jauch Judgment. 
Furthermore, the Leclere case also delimited the scope of Annex IIa. The case interpreted the rights of Mrs. Leclere, whose husband had formerly worked in Luxembourg, although the couple resided in Belgium. The husband was the victim of an accident at work in 1981, and thereafter received an invalidity pension paid by the Luxembourg social security services. With the birth of their child, they applied for various allowances in Luxembourg, among which was the maternity allowance. The application was turned down, since the couple did not fulfil the residence requirement for the benefit, which was one of the benefits explicitly listed in Regulation 1408/71's Annex IIa. Again the Court ruled that the maternity allowance had been invalidly placed in the Annex and, contrary to the opinion of the Luxembourg government, that its maternity benefit had to be exported according to Article 19(1)(b) of Regulation 1408/71.

The rulings in Hoever and Zachow, Molenaar, Jauch, and Leclere all extend the right to social security entitlements beyond the borders where the competent institution is situated. The cases of Hoever and Zachow and Molenaar show that social benefits cannot be insulated from the principles of Community law as a consequence of the way their purposes and means are defined nationally. The rulings of Jauch and Leclere demonstrate that although the social ministers of the Member States have collectively decided to tie certain benefits to national territory and although it is a political decision to which benefits this special rule applies, the political autonomy to administer according to that special rule is not free from judicial supervision.

In the new Regulation 883/2004, the principle of exportability has been given a more prominent position, advanced as Article $7 .{ }^{86}$ Whereas the Regulation does not ignore that special benefits may be linked to the place of residence, it is clear that national justification for maintaining residence rules for such benefits will be under closer supranational surveillance in the future. ${ }^{87}$ Against this new regulatory context, it seems obvious that the role of the Court will become even more central when the right balance between national principles of territoriality and the Community principle of exportability has to be decided.

\section{CONCLUDING REMARKS}

Furthered by cross-border movements of the people inhabiting the EU, their cases before the national courts and the ECJ, the Commission's recommendations and

86 That is against the former Art. 10.

87 Notable is that Para. 16 of Regulation 883/2004 mentions that the place of residence could be taken into account, instead of should be taken into account: 'Within the Community there is in principle no justification for making social security rights dependent on the place of residence of the person concerned; nevertheless, in specific cases, in particular as regards special benefits linked to the economic and social context of the person involved, the place of residence could be taken into account.' (emphasis added) 
proposals, and the Council's codification, a social security dimension in the EU has emerged and been consolidated.

The European dimension of welfare has come to cover all citizens of the Union, irrespective of their economic status. Attached as the social security dimension is to the free movement of persons, it confirms that European citizenship has indeed been ascribed a substantial content. When the newly adopted Residence Directive is implemented, European citizens will finally be able to settle freely in each others' states without the restrictive obligation to obtain a residence permit. Furthermore, their temporary access to the full scope of welfare has been widened and after five years of residence European citizens will be entitled to full social protection in any Member State of the Union. Against the historical background, where welfare constituted the social contract between the (nation-) state and its citizens, the progressive extension of intra-European welfare is an extraordinary example of how the bits and pieces of integration redefine competencies and intervene in virtually all areas of national law and policy.

Whereas de-nationalization of welfare in the EU has largely been achieved, de-territorialization has to date remained controversial. The legal-political dispute on the Community principle of exportability versus national principles of territoriality highlights litigation as a central part of decision-making as well as highlighting the ability of politics to react against such judicial decision-making. It thus exemplifies what may be the scope and limits of integration through law. In the case of special non-contributory benefits, politics managed to overturn law and overcame the institutional barrier of unanimity. The Court subsequently reacted in a receptive way, approving the special rule adopted by the Council. On the face of it, this collective restraint supports an argument of the priority of political power in the relation between law and politics, as for example advanced by Garret and others. ${ }^{88}$ However, the very recent litigation as well as the recent legislative reform suggest that territorial principles as effective means to demarcate welfare are subject to further challenge by Community law. When speculating about the future course of welfare integration in the EU, the ability of politicians to restrain the Court must be said to have been reduced significantly with enlargement. In an enlarged Union, it only takes one Member State out of twenty-five to agree with the interpretations of the Court and politics will not be in a collective position to act. The autonomy and authoritative position of the Court has been extended as a consequence of enlargement. The practical impact on the European dimension of welfare remains to be seen.

88 G. Garrett, D. Keleman and H. Schultz, 'The European Court of Justice, National Governments, and Legal Integration in the European Union', 52 International Organization, 1988, 147-76. 